\title{
Conjugative plasmid transfer from Escherichia coli to Clostridium acetobutylicum
}

\author{
D. Ross Williams, Danielle I. Young and Michael Young* \\ Department of Biological Sciences, University College of Wales, Aberystwyth, Dyfed SY23 3DA, UK
}

(Received 31 October 1989; revised 23 January 1990; accepted 9 February 1990)

\begin{abstract}
The conjugation mechanism of IncP plasmids may be employed to mobilize small non-conjugative plasmids from Escherichia coli to a wide range of different organisms. This strategy has been adapted for use with the Grampositive anaerobe, Clostridium acetobutylicum NCIB 8052. Several shuttle vectors containing replicons from pAMß1 (Enterococcus faecalis), pCB101 (Clostridium butyricum) or pWV01 (Streptococcus cremoris), together with the cis-acting oriT region of $\mathrm{RK} 2$, have been constructed, and transferred to and established in this organism. One of the vectors apparently contains a hot-spot for insertion of IS1. Conjugative mobilization of plasmids from $E$. coli will provide a useful alternative to electroporation for effecting gene transfer to this industrially important anaerobe.
\end{abstract}

\section{Introduction}

Clostridium acetobutylicum has long been employed for the industrial-scale production of acetone and butanol by fermentation of carbohydrates in low-grade agricultural wastes (reviewed by Jones \& Woods, 1986). More recently, it has been recognized (Morris, 1983) that this organism is potentially useful for synthesis of high-value products via stereo-selective or stereo-specific reductions that are difficult to accomplish chemically. A significant drawback to the industrial use of $C$. acetobutylicum has been a lack of suitable methods for genetic manipulation of this organism. However, various procedures for introducing plasmids have now been developed (reviewed by Young et al., 1989) and this should greatly improve prospects for future biotechnological exploitation of $C$. acetobutylicum.

These procedures include electroporation (Oultram $e t$ al., 1988a) and the mobilization of plasmids from Bacillus subtilis as cointegrates with pAM $\beta 1$ (Oultram et $a l ., 1987,1988 b)$. Since pAM $\beta 1$ is structurally unstable in B. subtilis (Van der Lelie \& Venema, 1987), transfer frequencies using the latter method are very low. An alternative procedure, that might be suitable for effecting plasmid transfer to $C$. acetobutylicum, has recently been described (Trieu-Cuot et al., 1987). It is based on the extremely broad-host-range Gram-negative conjugation system encoded by IncP plasmids such as RK2 (Thomas \& Smith, 1987). These plasmids are transferable to organisms representative of many genera, although in some instances (e.g. in Anabaena) they cannot replicate after transfer (Krishnapillai, 1988).

The conjugation machinery of IncP plasmids is remarkably non-specific and small non-conjugative plasmids can be mobilized to a variety of Gram-positive organisms. Trieu-Cuot et al. (1987) constructed a mobilizable vector containing a selectable marker and replication functions operative in both Escherichia coli and Gram-positive bacteria, into which was incorporated the cis-acting oriT site of RK2. This last component is the origin of conjugative DNA transfer, corresponding to the site at which the DNA duplex is nicked in preparation for transfer of a single strand from donor to recipient (Willets \& Wilkins, 1984; Guiney et al., 1988). All other conjugation functions were provided in trans on an IncP plasmid.

This paper establishes the utility of the IncP conjugation mechanism for mobilizing small, non-conjugative, bifunctional plasmids directly from $E$. coli to the Grampositive, obligate anaerobe, $C$. acetobutylicum.

\section{Methods}

Bacterial strains and plasmids. These are listed in Tables 1 and 2.

Culture media. Strains of E. coli were maintained on Luria-Bertani medium (which contains, per litre: tryptone, $10 \mathrm{~g}$; yeast extract, $5 \mathrm{~g}$; $\mathrm{NaCl}, 10 \mathrm{~g}$ ). Strains of $C$. acetobutylicum were maintained on clostridial -basal medium (CBM: O'Brien \& Morris, 1971). The media employed for filter mating experiments are described below. 
Table 1. Bacterial strains

\begin{tabular}{|c|c|c|}
\hline Strain & Genotype or phenotype* & Source/reference \\
\hline \multicolumn{3}{|l|}{ E. coli } \\
\hline HB10I & $\begin{array}{l}\mathrm{F}^{-} \text {hsdS } 20\left(\mathrm{r}_{\mathrm{B}}^{-}, \mathrm{m}_{\mathrm{B}}^{-}\right) \text {recA13 ara-14 lacY1 proA2 galK2 rpsL20 } \\
\left(\mathrm{Sm}^{\mathrm{R}}\right) \times x y l-5 \text { mtl-1 supE44 }\left(\lambda^{-}\right)\end{array}$ & Laboratory strain/Boyer \& Roulland-Dussoix (1969) \\
\hline $\mathrm{J} 53-1$ & $\mathrm{~F}^{-}$pro met $\operatorname{gyr} A 96\left(\mathrm{Na}^{\mathrm{R}}\right)(\lambda)$ & $\begin{array}{l}\text { C. M. Thomas, University of Birmingham/Clowes } \\
\text { \& Hayes (1968) }\end{array}$ \\
\hline JM107 & 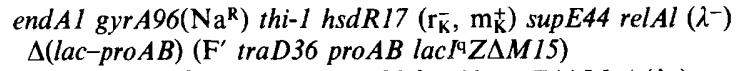 & Laboratory strain/Yanisch-Perron et al. (1985) \\
\hline SM10† & $\begin{array}{l}\mathrm{F}^{-} \text {thi-1 thr-1 leuB6 recA tonA2l lacY1 supE44 } \mathrm{Mu}_{\mathrm{c}}^{+}\left(\lambda^{-}\right) \\
{[\mathrm{RP} 4-2(\mathrm{Tc}:: \mathrm{Mu})] \mathrm{Km}^{\mathrm{R}} \mathrm{Tra}^{+}}\end{array}$ & P. Trieu-Cuot, Institut Pasteur/Simon et al. (1983) \\
\hline \multirow{2}{*}{\multicolumn{2}{|c|}{$\begin{array}{l}\text { C. acetobutylicum } \\
\text { NCIB } 8052\end{array}$}} & \\
\hline & & Laboratory strain \\
\hline
\end{tabular}

* Antibiotic resistances: $\mathrm{Sm}$, streptomycin; $\mathrm{Na}$, nalidixic acid; $\mathrm{Km}$, kanamycin.

† RP4-2(Tc:: $\mathrm{Mu}$ ) is integrated into the bacterial chromosome.

Table 2. Plasmids

\begin{tabular}{|c|c|c|c|}
\hline Plasmid & Relevant characteristics* & Gram-positive replicon & Source or reference \\
\hline pAT187 & $\mathrm{Tra}^{-} \mathrm{Mob}^{+} \mathrm{Km}^{\mathrm{R}}$ & $\mathrm{pAM} \beta 1$ & Trieu-Cuot et al. (1987) \\
\hline pRK $24 \dagger$ & $\mathrm{Tra}^{+} \mathrm{Mob}^{+}$IncP $\mathrm{Ap}^{\mathrm{R}} \mathrm{Tc}^{\mathrm{R}} \operatorname{trp} E$ & - & Thomas \& Smith (1987) \\
\hline R702‡ & $\mathrm{Tra}^{+} \mathrm{Mob}^{+}$IncP $\mathrm{Km}^{\mathrm{R}} \mathrm{Tc}^{\mathrm{R}} \mathrm{Sm}^{\mathrm{R}} \mathrm{Su}^{\mathrm{R}} \mathrm{Hg}^{\mathrm{R}}$ & - & Hedges \& Jacob (1974) \\
\hline pCB101 & $\mathrm{Tra}^{-} \mathrm{Mob}^{-}$cryptic & pCB101 & Collins et al. (1985) \\
\hline pGK13 & $\mathrm{Tra}^{-} \mathrm{Mob}^{-} \mathrm{Cm}^{\mathrm{R}} \mathrm{Em}^{\mathrm{R}}$ & pWV01 & Kok et al. (1984) \\
\hline pUC8 $\beta \S$ & $\mathrm{Tra}^{-} \mathrm{Mob}^{-} \mathrm{Ap}^{\mathrm{R}}$ & - & Larkin et al. (1986) \\
\hline pMTL30 & $\mathrm{Tra}^{-} \mathrm{Mob}^{+} \mathrm{Ap}^{\mathrm{R}} \mathrm{Em}^{\mathrm{R}}$ lac $Z^{\prime}$ & - & Williams et al (1990) \\
\hline pMTL31 & $\mathrm{Tra}^{-} \mathrm{Mob}^{+} \mathrm{Ap}^{\mathrm{R}} \mathrm{Em}^{\mathrm{R}}$ lac $Z^{\prime}$ & - & Williams et al (1990) \\
\hline pMTL500E & $\mathrm{Tra}^{-} \mathrm{Mob}^{-} \mathrm{Ap}^{\mathrm{R}} \mathrm{Em}^{\mathrm{R}}$ lac $Z^{\prime}$ & $\mathrm{pAM} \beta 1$ & Oultram et al. $(1988 a)$ \\
\hline pCTC1\| & $\mathrm{Tra}^{-} \mathrm{Mob}^{+} \mathrm{Ap}^{\mathrm{R}} \mathrm{Em}^{\mathrm{R}}$ & $\mathrm{pAM} \beta 1$ & This paper \\
\hline pCTC3\| & $\mathrm{Tra}^{-} \mathrm{Mob}^{+} \mathrm{Cm}^{\mathrm{R}} \mathrm{Em}^{\mathrm{R}}$ & pWV01 & This paper \\
\hline pCTC40\| & $\mathrm{Tra}^{-} \mathrm{Mob}^{+} \mathrm{Ap}^{\mathrm{R}} \mathrm{Em}^{\mathrm{R}}$ & рАМ $\beta 1$ & This paper \\
\hline pCTC401\| & $\mathrm{Tra}^{-} \mathrm{Mob}^{+} \mathrm{Ap}^{\mathrm{R}} \mathrm{Em}^{\mathrm{R}}$ & pAM $\beta 1::$ IS 1 & This paper \\
\hline pCTC41\| & $\mathrm{Tra}^{-} \mathrm{Mob}^{+} \mathrm{Ap}^{\mathrm{R}} \mathrm{Em}^{\mathrm{R}}$ & pAM $\beta 1$ & This paper \\
\hline pCTC511\| & $\mathrm{Tra}^{-} \mathrm{Mob}^{+} \mathrm{Ap}^{\mathrm{R}} \mathrm{Em}^{\mathrm{R}}$ & pCB101 & This paper \\
\hline
\end{tabular}

* The Mob+ phenotype is conferred by oriT. Antibiotic resistances: Ap, ampicillin; Tc, tetracycline; Su, sulphonamide; $\mathrm{Hg}$, merbromin; Cm, chloramphenicol; Em, erythromycin $\left(M^{2}{ }^{R}\right)$; others are as indicated in the footnotes to Table 1 .

$\dagger \mathrm{pRK} 24$ is RK2 with the $\mathrm{Km}^{\mathrm{R}}$ gene inactivated by insertion of a HindIII fragment bearing trpE.

$\ddagger$ R702 lacks Tn1 and does not confer ampicillin resistance (Hedges \& Jacob, 1974).

$\S \mathrm{pUC} 8 \beta$ contains a $240 \mathrm{bp}$ internal HaeIII fragment of IS 1 which has homology only with the larger PvuII fragment of IS 1 .

$\|$ Details of the construction of these plasmids are given in the legend to Fig. 1.

Filter mating procedure. The optimized procedure (Williams et al., $1990)$ was as follows. Donor strains of $E$. coli were grown overnight aerobically to $\mathrm{OD}_{600}>4.0$ (about $5 \times 10^{9}$ c.f.u. $\mathrm{ml}^{-1}$ ) in brain heart infusion broth (BHIB) supplemented with antibiotics selective for the mobilizable plasmids that they contained. The recipient strain, $C$. acetobutylicum NCIB 8052, was grown overnight anaerobically in TYG medium (which contains, per litre: tryptone, $30 \mathrm{~g}$; yeast extract, $20 \mathrm{~g}$; glucose $5 \mathrm{~g}$; sodium mercaptoacetate, $1 \mathrm{~g}$ ). Exponentially growing cultures, at an $\mathrm{OD}_{600}$ of 0.6-1.2 (about $5 \times 10^{7}$ c.f.u. $\mathrm{ml}^{-1}$ ), were used for matings. Donor and recipient bacteria were mixed in a $1000: 1$ ratio, by pipetting $0.2 \mathrm{ml}$ of the recipient culture into $2 \mathrm{ml}$ of the donor culture. Bacteria from this mating mixture were deposited by filtration on a cellulose nitrate membrane (Whatman $\mathrm{WCN}, 0.45 \mu \mathrm{m}$ pore size, $2.5 \mathrm{~cm}$ diam.). Filters were incubated overnight, bacteria uppermost, on plates containing reinforced clostridial medium (RCM) solidified with $1.5 \%(\mathrm{w} / \mathrm{v})$ agar and spread with $2 \mathrm{mg}$ catalase (Sigma). Bacteria were harvested from the filter the following morning by vortex mixing in $0.5 \mathrm{ml}$ holding buffer (HB: $25 \mathrm{mM}$-potassium phosphate $\mathrm{pH} \mathrm{7.0,}$ $1 \mathrm{mM}-\mathrm{MgSO}_{4}$ ) and serial dilutions were prepared in this buffer. Viable counts of donor and recipient bacteria were obtained by plating on BHIB and CBM, respectively; recipient and donor bacteria were counter-selected by aerobic incubation and by incorporation of trimethoprim $\left(10 \mu \mathrm{g} \mathrm{ml}^{-1}\right)$, respectively. Transconjugants were selected anaerobically on CBM supplemented with trimethoprim $\left(10 \mu \mathrm{g} \mathrm{ml}^{-1}\right)$ and either kanamycin $\left(80 \mu \mathrm{g} \mathrm{ml}^{-1}\right)$ or erythromycin $\left(10 \mu \mathrm{g} \mathrm{ml}^{-1}\right)$, as appropriate. All manipulations were carried out at $37^{\circ} \mathrm{C}$; those involving $C$. acetobutylicum were carried out in an anaerobic cabinet (Don Whitley Scientific). Frequencies of plasmid transfer are expressed as the number of transconjugants per donor or recipient colony formed after the mating period.

Two attempts were made to effect plasmid transfer to $C$. acetobutylicum strains P262, DSM 1731 and ATCC 824 using the above 
procedure, which had been optimized for strain NCIB 8052 (Williams et al., 1990). They were unsuccessful. As has been noted previously (Woolley et al., 1989), the last two strains are not closely related to strain NCIB 8052. Strain P262, which is closely related to strain NCIB 8052, produces copious amounts of extracellular polysaccharide material, which may interfere with filter mating. It would therefore appear that the technique will require modification for use with these organisms.

$E$. coli donor strains containing $\mathbf{R} 702$ were constructed in two steps. The plasmid to be mobilized was introduced into strain HB101 by transformation, after which the IncP helper plasmid was introduced by conjugation from strain J53-I. Matings between $E$. coli strains were carried out according to the method of Trieu-Cuot \& Courvalin (1985).

The presence of authentic plasmid DNA in transconjugants was routinely verified by electrophoretic analysis of the products obtained after digestion with a variety of restriction endonucleases.

Molecular methods. The methods employed for DNA extraction and manipulation were those described by Maniatis et al. (1982). For smallscale plasmid extraction from $C$. acetobutylicum, the bacterial pellet from $3 \mathrm{ml}$ of an overnight CBM culture containing appropriate antibiotics was suspended in $100 \mu \mathrm{l} 25 \%$ (w/v) sucrose, $25 \mathrm{mM}$ Tris/ $\mathrm{HCl} \mathrm{pH} 8.0,10 \mathrm{mM}$-EDTA containing $10 \mathrm{mg}^{\circ}$ lysozyme $\mathrm{ml}^{-1}$ and incubated for $1 \mathrm{~h}$ at $37^{\circ} \mathrm{C}$ before proceeding with the standard alkaline lysis method (Maniatis et al., 1982). This initial step was carried out anaerobically.

Restriction endonculeases, T4 DNA ligase, Klenow polymerase and T4 polymerase were used according to the manufacturers' instructions (variously: Northumbria Biologicals, Boehringer, Pharmacia, GibcoBRL and Stratagene). DNA fragments were purified using 'Geneclean' (Stratech). Transformation of E. coli strains JM107 and HB101 was done by the Simanis method (Hanahan, 1985).

\section{Results}

\section{Transfer of plasmid pAT187 to C. acetobutylicum}

Trieu-Cuot et al. (1987) have shown that plasmid pAT187 (Fig. 1), can be mobilized by an IncP plasmid from an E. coli donor strain into a wide range of Grampositive bacteria. pAT187 is a derivative of pBR322, into which has been incorporated the oriT segment of RK2, together with a $5 \cdot 1 \mathrm{~kb} E c o$ RI fragment of $\mathrm{pAM} \beta 1$, which assures replication in Gram-positive bacteria. It also contains the aphA-3 gene from $\mathrm{Tn} 1545$, which encodes resistance to kanamycin and is selectable in a wide range of organisms, both Gram-positive and Gram-negative. Both the replication origin of $\mathrm{pAM} \beta 1$ and the Tn1545 aphA-3 gene are expressed in C. acetobutylicum (Oultram \& Young, 1985; Reysset \& Sebald, 1985; Yu \& Pearce', 1986; Woolley et al., 1989).

Initial experiments were carried out to determine whether pAT187 could be mobilized into $C$. acetobutylicum from an E. coli donor strain (HB101) harbouring the IncP plasmid pRK24. Although kanamycin is only weakly selective in anaerobic organisms, judicious adjustment of the antibiotic concentration in the selective medium enabled plasmid transfer to be detected (Table 3). The presence of pAT187 in transconjugants obtained from several independent matings was con- firmed by analysis of plasmid DNA with a variety of restriction endonucleases. Representative data are shown in Fig. 2.

\section{Construction and mobilization of a high-copy-number vector}

The weak staining intensity of plasmid DNA in lysates of C. acetobutylicum (Fig. 2) suggests that pAT187 replicates at low copy number in this organism. A highcopy-number vector, pCTC1 (Fig. 1), was constructed by inserting a small restriction fragment carrying oriT from RK2 into pMTL500E (Oultram et al., 1988a). The vector, which is based on the pMTL20 plasmid backbone (Chambers et al., 1988 - see also below) contains a $2.8 \mathrm{~kb}$ sub-fragment of the pAM $\beta 1$ replication region, which promotes replication at high copy number in C. acetobutylicum (Swinfield et al., 1990). It also contains the $\mathrm{Em}^{\mathrm{R}}$ gene of $\mathrm{pAM} \beta 1$ (Brehm et al., 1987), which is more readily selectable in C. acetobutylicum than is the $\mathrm{Km}^{\mathrm{R}}$ gene of pAT187. Plasmid pCTC1 was transferred to $C$. acetobutylicum from two $E$. coli donors, strain HB101 harbouring the autonomous IncP plasmid R702 and strain SM10 (Simon et al., 1983), in which the tra functions are present on the bacterial chromosome as an integrated copy of RP4-2(Tc: : Mu) (Table 3). Plasmid DNA was much more prominent in lysates of $C$. acetobutylicum strains harbouring pCTC1 than in those of strains harbouring pAT187 (Fig. 2), suggesting that pCTC1 is indeed maintained at a higher copy number in this organism than is pAT187.

\section{Screening of replicons for ability to function in C. acetobutylicum}

A pair of vectors, pMTL30 and pMTL31 (Fig. 1), were constructed, containing oriT inserted in either orientation in the pMTL20E backbone (Minton et al., 1988). The ColE1-derived replication origin of the pMTL plasmids is the same as that of the pUC plasmids (Vieira \& Messing, 1982; Yanisch-Perron et al., 1985). As a result of a single base pair change in the RNAI/RNAII region, the pMTL and pUC plasmids replicate at a threefold higher copy number than pBR322 in $E$. coli (Chambers et al., 1988). Both pMTL30 and pMTL31 were equally efficiently mobilized in matings between $E$. coli strains (data not shown). They lack a replication origin active in Gram-positive bacteria and hence they cannot become established in C. acetobutylicum (Table 3). Replication origins from plasmids found in Grampositive bacteria were inserted into the polylinker regions of pMTL30 and pMTL31 to test their ability to function in C. acetobutylicum.

Initially, plasmids pCTC40 and pCTC41 were con- 

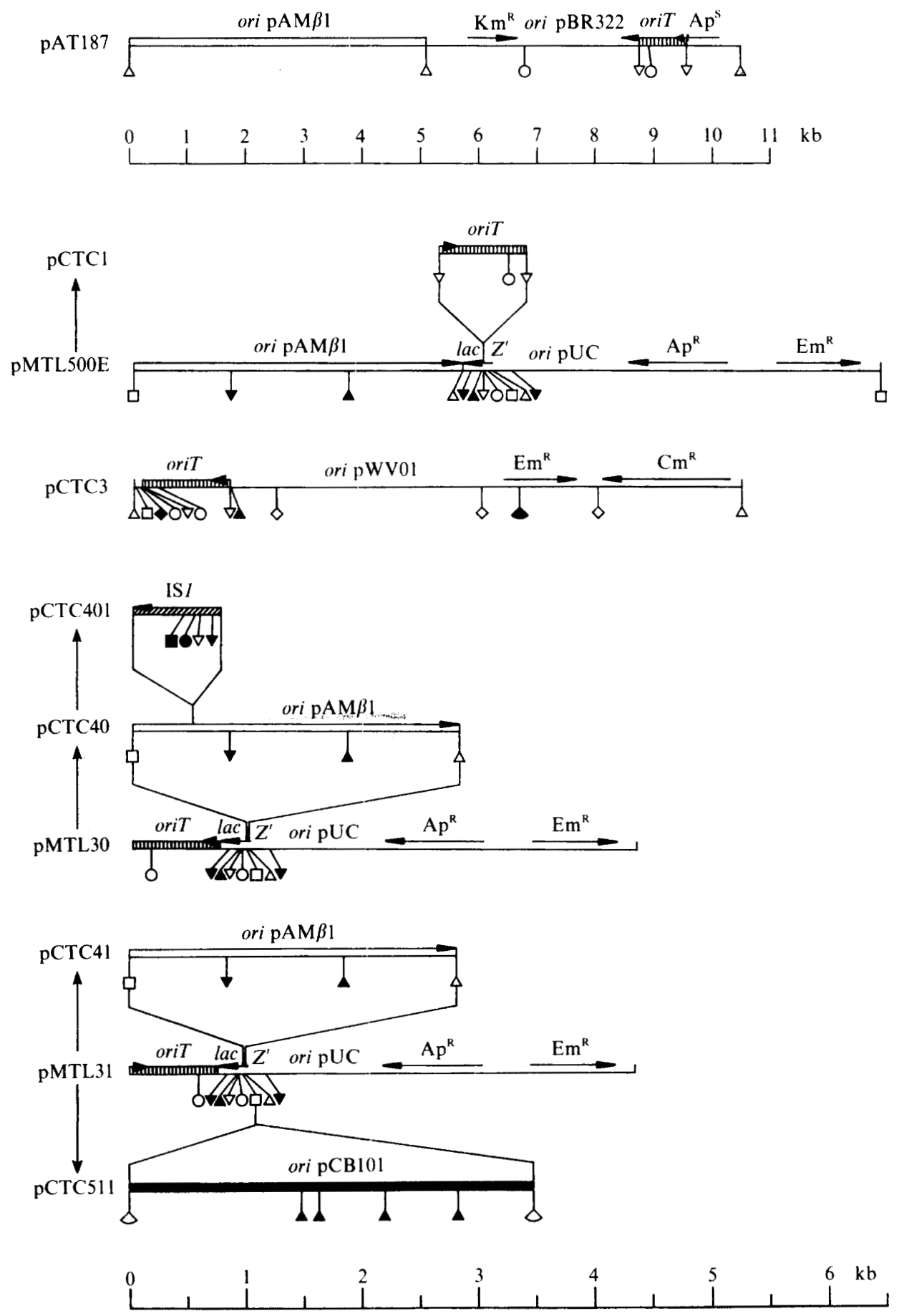

Fig. 1. Plasmids. These were constructed as follows: A $760 \mathrm{bp} P s t \mathrm{I}$ fragment from pAT187, containing oriT, was inserted into the $P$ stI site of pMTL500E to give pCTCl. The oriT segment was excised from pCTC1 on an 850 bp Eco RI-HindIII fragment and inserted into EcoRI- and HindIII-digested pGK13 (Kok et al., 1984) to generate pCTC3. pCTC40 and pCTC41 were constructed by inserting a 2.8 $\mathrm{kb} E c o \mathrm{RI}-$ Bam HI fragment of pMTL500E, containing the pAM $\beta 1$ replication origin, into Eco RI- and BamHI-digested pMTL 30 and pMTL31, respectively. pCTC401 arose by spontaneous insertion of IS $l$ into pCTC40. A $3.5 \mathrm{~kb}$ Sau $3 \mathrm{~A}$ fragment of pCB 101 , bearing the replication origin, was inserted into the BamHI site of pMTL31 to give pCTC511. For all plasmids except pCTC3 (see text), the replication origin allowing plasmid maintenance in $E$. coli (denoted pUC) is that of pUC8 (Vieira \& Messing, 1982). All plasmids except pCTC3 are based on the pMTL20 backbone (Chambers et al., 1988; Minton et al., 1988). Antibiotic resistances are denoted as in Table $\mathrm{I}$ and 2. In pCTC3, the gene conferring resistance to Em is from pE194; in all other plasmids it is derived from pAM $\beta 1$. The genes conferring resistance to $\mathrm{Cm}$ and $\mathrm{Km}$ are from pC194 and $\mathrm{Tn} 1545$ (aphA-3), respectively. Restriction sites are denoted as follows: $\bigcirc$,

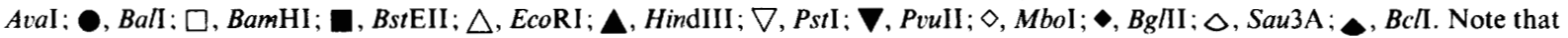
plasmid pAT187 is drawn to a different scale. 


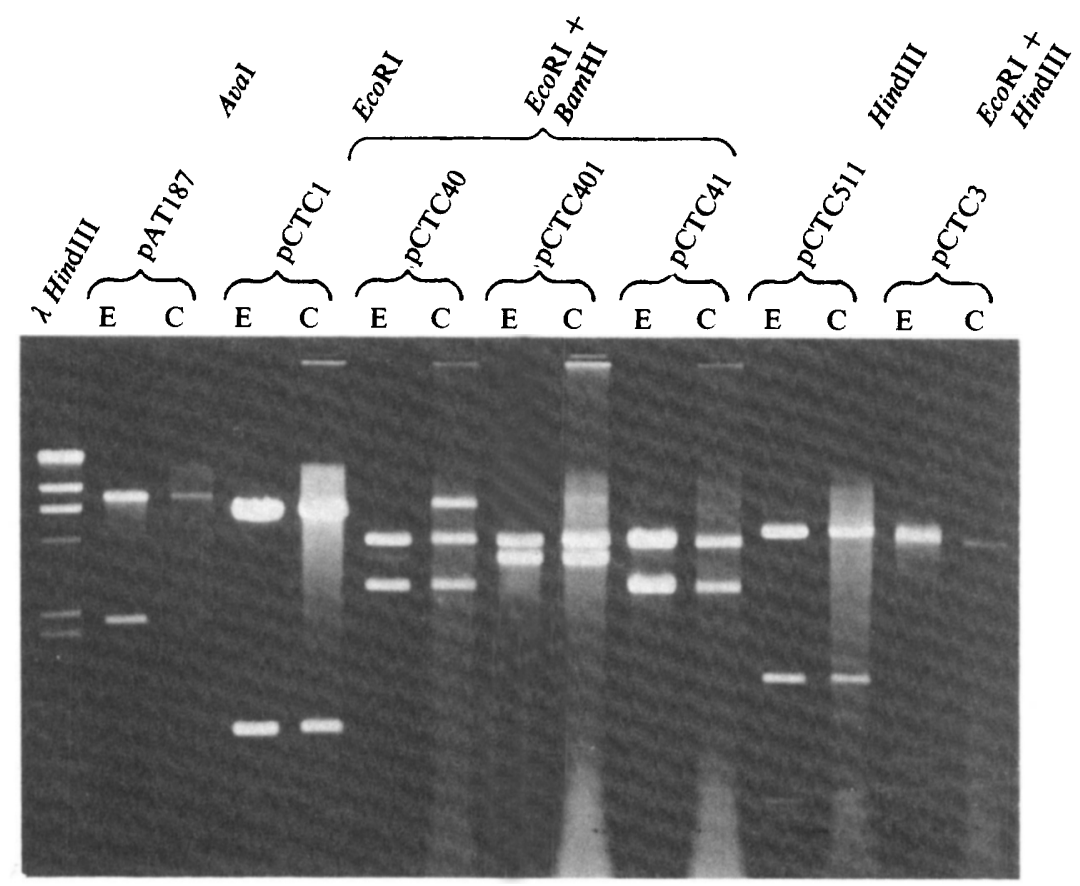

Fig. 2. Detection of plasmids in transconjugants. Plasmids extracted from E. coli $\mathrm{HB} 101$ (E) and C. acetobutylicum NCIB 8052 (C) were digested with the restriction endonucleases indicated. In the lane containing pCTC40 from E. coli a faint band resulting from insertion of IS $I$ into the smaller EcoRI-BamHI fragment is visible between the two brighter bands. This band is not observed with pCTC40 extracted from C. acetobutylicum (the topmost band in this case results from partial digestion).

Table 3. Frequencies of plasmid transfer to C. acetobutylicum

\begin{tabular}{llrr}
\hline \hline Plasmid & Mobilization* & Frequency per donor $\dagger$ & Frequency per recipient \\
\hline pAT187 & pRK24 & $2 \cdot 9( \pm 4 \cdot 0) \times 10^{-7}[3]$ & $1 \cdot 4( \pm 1 \cdot 4) \times 10^{-6}[3]$ \\
pCTC1 & RP4-2(Tc::Mu) & $6 \cdot 0( \pm 4 \cdot 4) \times 10^{-7}[5]$ & $1 \cdot 1( \pm 1 \cdot 2) \times 10^{-5}[5]$ \\
pCTC1 & R702 & $3 \cdot 8( \pm 6 \cdot 0) \times 10^{-6}[10]$ & $2 \cdot 8( \pm 3 \cdot 4) \times 10^{-5}[10]$ \\
pCTC40 & R702 & $3 \cdot 4( \pm 0 \cdot 5) \times 10^{-6}[3]$ & $1 \cdot 5( \pm 0 \cdot 3) \times 10^{-5}[3]$ \\
pCTC401 & R702 & $2 \cdot 6( \pm 1 \cdot 9) \times 10^{-6}[4]$ & $3 \cdot 6( \pm 2 \cdot 4) \times 10^{-5}[4]$ \\
pCTC41 & R702 & $6 \cdot 1( \pm 6 \cdot 0) \times 10^{-6}[3]$ & $4 \cdot 7( \pm 2 \cdot 8) \times 10^{-5}[3]$ \\
pCTC511 & R702 & $2 \cdot 7( \pm 5 \cdot 2) \times 10^{-7}[8]$ & $8 \cdot 1( \pm 13 \cdot 7) \times 10^{-7}[8]$ \\
pCTC3 & RP4-2(Tc::Mu) & $2 \cdot 0( \pm 1 \cdot 2) \times 10^{-6}[3]$ & $1 \cdot 0( \pm 0 \cdot 3) \times 10^{-5}[3]$ \\
pMTL30 $\ddagger$ & RP4-2(Tc::Mu) & $<3 \cdot 7 \times 10^{-9}[1]$ & $<3 \cdot 5 \times 10^{-9}[1]$ \\
pMTL31 & RP4-2(Tc::Mu) & $<2 \cdot 1 \times 10^{-9}[1]$ & $<3 \cdot 3 \times 10^{-9}[1]$ \\
pMTL500E $\ddagger$ & RP4-2(Tc::Mu) & $<7 \cdot 4 \times 10^{-10}[1]$ & $<4 \cdot 4 \times 10^{-9}[1]$ \\
\hline \hline
\end{tabular}

${ }^{*}$ The donor strain containing pRK24 or R702 was HB101. RP4-2(Tc::Mu) is present as a chromosomal insertion in strain SM10.

$\dagger$ Values in parentheses are population standard deviations of the means $\left(\sigma_{n-1}\right)$; the number of determinations, $n$, is shown in square brackets.

$\ddagger$ Plasmids pMTL30, pMTL31 and pMTL500E did not produce any transconjugants.

structed by inserting the replication origin of $\mathrm{pAM} \beta 1$ into pMTL30 and pMTL31, respectively (Fig. 1). These plasmids contain the same elements as pCTC1, except that the positions of the $\mathrm{pAM} \beta 1$ replication origin and the oriT segment are exchanged. The frequencies of transfer of pCTC 40 and pCTC41 from an E. coli donor strain harbouring $\mathrm{R} 702$ to $C$. acetobutylicum were similar
(Table 3). This indicates that mobilization was equally efficient irrespective of the orientation of oriT. The frequency of mobilization of both plasmids was also similar to that observed with pCTC1, indicating that the relative positions of the pAM $\beta 1$ replication origin and oriT have no pronounced effect on plasmid mobilization frequency. 


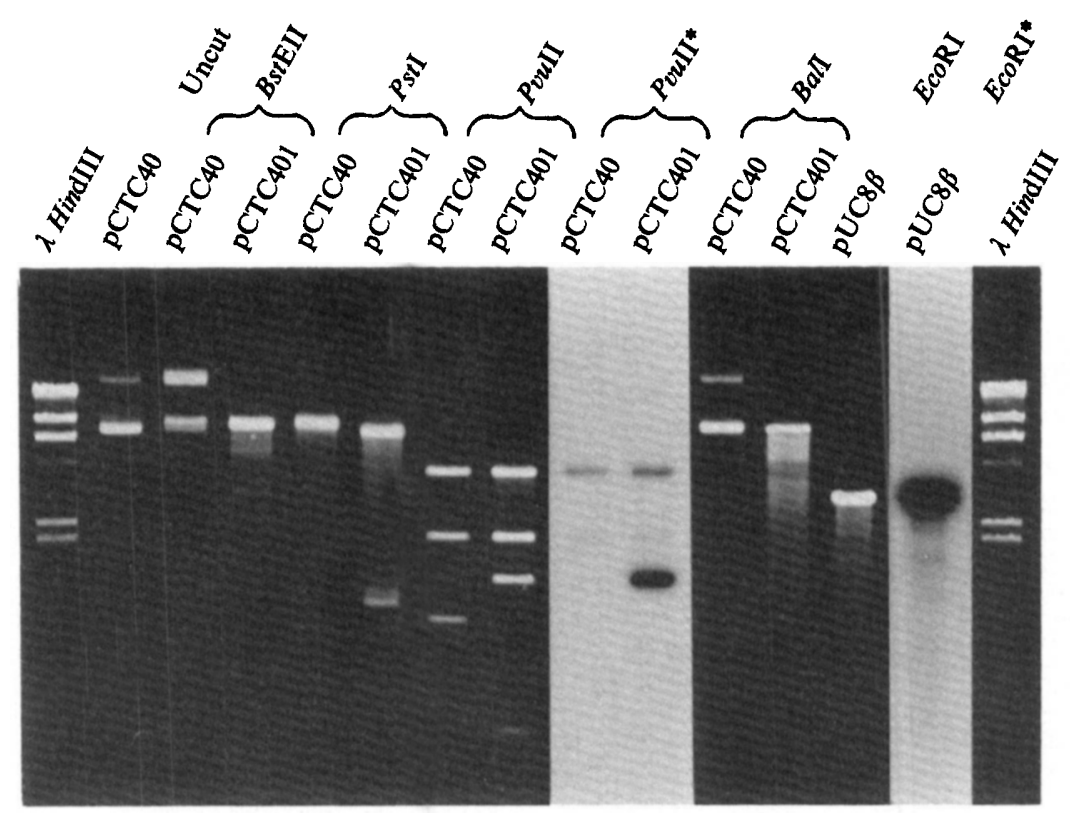

Fig. 3. Insertion of IS 1 into pCTC40. Comparison of the sensitivity of pCTC40 and pCTC401 to a variety of restriction endonucleases. Lanes marked with an asterisk are DNA samples hybridized with the fragment of pUC8 $\beta$ that detects IS 1 (see Table 2). Note that this probe contained small amounts of contaminating pUC8 sequences that resulted in weak hybridization with the pMTL20 backbone of pCTC40 and pCTC401.

Plasmid pCTC511 (Fig. 1) contains the replication functions of plasmid pCB101 from Clostridium butyricum NCIB 7423 (Minton \& Morris, 1981 ; Collins et al., 1985). pCB101 belongs to the extensive family of plasmids found in Gram-positive bacteria that replicate via a single-stranded DNA intermediate (Minton \& Oultram, 1988; Young et al., 1989; Gruss \& Ehrlich, 1989). pCTC511 was transferred to $C$. acetobutylicum from $E$. coli strain HB101 harbouring R702 at a frequency slightly lower than those obtained for the various pCTC plasmids containing the $\mathrm{pAM} \beta 1$ replication functions (Table 3). It appears to replicate at high copy number in C. acetobutylicum as indicated by the staining intensity of plasmid DNA in lysates (Fig. 2).

Lastly, plasmid pCTC3 (Fig. 1), which contains the replication origin of the Streptococcus cremoris plasmid pWV01 (Vosman \& Venema, 1983), was tested for ability to replicate in C. acetobutylicum. Like pCB101, pWV01 belongs to the extensive family of plasmids that replicate via a single-stranded DNA intermediate (Peijnenburg et al., 1989; A. Gruss \& S. D. Ehrlich, personal communication). Since the $\mathrm{pWV} 01$ replication functions are active in both Gram-positive and Gram-negative hosts (Kok et al., 1984), pCTC3 was constructed without incorporating the pMTL plasmid backbone. In consequence, it is the smallest of the vectors constructed here (Fig. 1). Plasmid pCTC3 was mobilized from E. coli to $C$. acetobutylicum at a frequency similar to that observed for plasmids containing the replication origin of plasmid
pAM $\beta 1$ (Table 3). The weak staining intensity of plasmid DNA in lysates of $C$. acetobutylicum strains harbouring pCTC3 (Fig. 2) suggests that this plasmid replicates at low copy number in this organism.

\section{Instability of plasmid pCTC40 in E. coli}

On several separate occasions, it was noted that strains of $E$. coli independently transformed with pCTC40 contained an enlarged derivative. The insertions (about 750 bp) introduced extra sites for PstI and PvuII and new unique sites for BstEII and BaII into the plasmid (Fig. 3). In order to keep pCTC40 intact in $E$. coli, it was necessary to maintain strains at $37^{\circ} \mathrm{C}$; when left on the bench and then subcultured, they were invariably found to harbour enlarged derivatives. This behaviour, and the properties outlined above, suggested that the instability of plasmid pCTC40 arose from the insertion of a copy of IS 1 . This was confirmed by Southern hybridization (Fig. 3), using an internal segment of IS1 as probe (Larkin et al., 1986). Analysis of several independent isolates with a variety of restriction endonucleases suggested that ISI always inserted into the same position $( \pm 50 \mathrm{bp})$, within the DNA segment encoding the pAM $\beta 1$ replication functions. Nevertheless, the enlarged derivative, denoted pCTC401, was transferred from $E$. coli to $C$. acetobutylicum at a frequency comparable to that of the parental plasmid, pCTC40 (Table 3). 


\section{Discussion}

The results reported here establish a convenient alternative to electroporation (Oultram et al., 1988a), or conjugative mobilization from $B$. subtilis (Oultram et al., 1987), for introducing plasmids into $C$. acetobutylicum. Using this new method for plasmid transfer, it has been established that replication functions of plasmids originating in three different heterologous hosts can function in $C$. acetobutylicum. Derivatives containing the replication region of plasmid pAM $\beta 1$ from $E$. faecalis have previously been transferred to this organism by conjugation from B. subtilis (Oultram \& Young, 1985) and also by electroporation (Oultram et al., 1988a). The apparent difference in copy number in $C$. acetobutylicum between the plasmid (pAT187) which contains a $5 \cdot 1 \mathrm{~kb}$ EcoRI fragment of $\mathrm{pAM} \beta 1$ and replicates at low copy number, and several others (pCTC1, pCTC40 and pCTC41) which contain a $2.8 \mathrm{~kb}$ sub-fragment and replicate at high copy number, is in agreement with the results of Swinfield et al. (1990), and suggests that the $2 \cdot 3 \mathrm{~kb}$ segment missing from the sub-fragment contains an element that negatively controls plasmid copy number. pCTC511, containing the replication functions of pCB101 from $C$. butyricum, replicated at high copy number in $C$. acetobutylicum. In agreement with this finding, another plasmid containing the pCB101 replication functions has recently been transferred to this organism by electroporation (reviewed by Young et al., 1989). Lastly, the finding that pCTC3, containing the replication functions of plasmid pWV01 from $S$. cremoris, was able to replicate at low copy number in $C$. acetobutylicum further extends the very wide range of organisms, both Gram-positive and Gram-negative, in which the replication functions of this plasmid are active (Kok et al., 1984).

As far as is known, the only difference between pCTC40 and pCTC41 is the orientation of the oriT segment. Yet the former, but not the latter, tended to act as a target for ISI insertion; the element always (six independent isolates have been analysed) inserted into the same region $( \pm 50 \mathrm{bp})$. Why this region acts as an apparent hotspot for ISI transposition in pCTC40, but not in pCTC41, is not known. It is also of interest that insertion of IS 1 did not impair the ability of pCTC401 to replicate in either $C$. acetobutylicum or B. subtilis (data not shown for the latter). Swinfield et al. (1990) have shown that a deletion extending into this region of the $2.8 \mathrm{~kb}$ sub-fragment of the pAM $\beta 1$ replication region abolishes its ability to function in $B$. subtilis. Nucleotide sequencing, to determine the precise insertion points in several independent isolates, might prove informative in relation to both the $\mathrm{pAM} \beta 1$ replication region and the nature of the apparent hotspot for ISI insertion.
Finally, the results of this investigation further extend the extraordinary range of organisms into which plasmids may be transferred from $E$. coli by conjugative mobilization (Buchanan-Wollaston et al., 1987; TrieuCuot et al., 1987; Mazodier et al., 1989; Heinemann \& Sprague, 1989). They also establish that transfer occurs under strictly anaerobic conditions and hence, IncP plasmids may prove useful for effecting plasmid transfer from $E$. coli to other recalcitrant anaerobes, such as methanogens, for which conventional methods of gene transfer have so far proved ineffective.

We thank C. M. Thomas, N. P. Minton, J. D. Oultram, P. TrieuCuot and D. R. Woods for generously providing strains and plasmids. This work was carried out within the framework of the EEC Biotechnology Action Programme (contract no. BAP-0044-UK). The financial support of the SERC Biotechnology Directorate is also gratefully acknowledged.

\section{References}

Boyer, H. W. \& Roulland-Dussorx, D. (1969). A complementation analysis of the restriction and modification of DNA in Escherichia coli. Journal of Molecular Biology 41, 459-472.

Brehm, J., Salmond, G. \& Minton, N. P. (1987). Sequence of the adenine methylase gene of the Streptococcus faecalis plasmid pAM $\beta 1$. Nucleic Acids Research 15, 3177.

Buchanan-Wollaston, V., Passiatore, J. E. \& Cannon, F. (1987). The mob and oriT mobilization functions of a bacterial plasmid promote its transfer to plants. Nature, London 328, 172-175.

Chambers, S. P., Prior, S. E., Barstow, D. A. \& Minton, N. P (1988). The pMTL nic ${ }^{-}$cloning vectors, I. Improved pUC polylinker regions to facilitate the use of sonicated DNA for nucleotide sequencing. Gene 68, 139-149.

Clowes, R. C. \& HaYes, W. (1968). Experiments in Microbial Genetics. Oxford \& Edinburgh: Blackwell.

Collins, M. E., Oultram, J. D. \& Young, M. (1985). Identification of restriction fragments from two cryptic Clostridium butyricum plasmids that promote the establishment of a replication-defective plasmid in Bacillus subtilis. Journal of General Microbiology 131, 2097-2105.

Gruss, A. \& EHrLICH, S. D. (1989). The family of highly interrelated single-stranded deoxyribonucleic acid plasmids. Microbiological Reviews 53, 231-241.

Guiney, D. G., Deiss, C. \& Simnad, V. (1988). Location of the relaxation complex nick site within the minimal origin of transfer region of RK2. Plasmid 20, 259-265.

HaNaHAN, D. (1985). Techniques for transformation of E. coli. In DNA Cloning, a Practical Approach, vol. 1, pp. 109-135. Edited by D. M. Glover. Oxford: IRL Press.

HEDGES, R. W. \& JACOB, A. E. (1974). Transposition of ampicillin resistance from RP4 to other replicons. Molecular and General Genetics 132, 31-34.

Heinemann, J. A. \& Sprague, G. F., JR (1989). Bacterial conjugative plasmids mobilize DNA transfer between bacteria and yeast. Nature, London 340, 205-209.

JoNEs, D. T. \& Woods, D. R. (1986). Acetone-butanol fermentation revisited. Microbiological Reviews 50, 484-524.

KoK, J., Van der Vossen, J. M. B. M. \& Venema, G. (1984). Construction of plasmid cloning vectors for lactic streptococci which also replicate in Bacillus subtilis and Escherichia coli. Applied and Environmental Microbiology 48, 726-731.

KRISHNAPILlaI, V. (1988). Molecular genetic analysis of bacterial plasmid promiscuity. FEMS Microbiology Reviews 54, 223-238. 
Larkin, M. J., Blakely, G. W., Williams, D. R. \& Patrick, S (1986). Screening for the presence of ISI in the genus Bacteroides. FEMS Microbiology Letters 37, 331-334.

Maniatis, T., Fritsch, E. F. \& SambrooK, J. (1982). Molecular Cloning, a Laboratory Manual. Cold Spring Harbor, NY: Cold Spring Harbor Laboratory.

Mazodier, Ph., Petter, R. \& Thompson, C. (1989). Intergeneric conjugation between Escherichia coli and Streptomyces species. Journal of Bacteriology 171, 3583-3585.

Minton, N. P. \& MoRris, J. G. (1981). Isolation and partial characterization of three cryptic plasmids from strains of Clostridium butyricum. Journal of General Microbiology 127, 325-331.

Minton, N. P. \& Oultram, J. D. (1988). Host vector systems for gene cloning in Clostridium. Microbiological Sciences 5, 310-315.

Minton, N. P., Brehm, J. K., Oultram, J. D., Swinfield, T. J. \& THOMPSON, D. E. (1988). Construction of plasmid vector systems for gene transfer in Clostridium acetobutylicum. In Anaerobes Today, pp. 125-140. Edited by J. M. Hardie \& S. P. Borriello. Chichester: Wiley.

Morris, J. G. (1983). Anaerobic fermentations - some new possibilities. Biochemical Society Symposia 48, 147-172.

O'BriEN, R. W. \& MORRIS, J. G. (1971). Oxygen and the growth and metabolism of Clostridium acetobutylicum. Journal of General Microbiology 68, 307-318.

Oultram, J. D. \& Young, M. (1985). Conjugal transfer of plasmid pAM $\beta 1$ from Streptococcus lactis and Bacillus subtilis to Clostridium acetobutylicum. FEMS Microbiology Letters 27, 129-134.

Oultram, J. D., Davies, A. \& Young, M. (1987). Conjugal transfer of a small plasmid from Bacillus subtilis to Clostridium acetobutylicum by cointegrate formation with plasmid pAM $\beta 1$. FEMS Microbiology Letters 42, 113-119.

Oultram, J. D., Loughlin, M., Swinfield, T. J., Brehm, J. K., THOMPSON, D. E. \& MinToN, N. P. (1988a). Introduction of plasmids into whole cells of Clostridium acetobutylicum by electroporation. FEMS Microbiology Letters 56, 83-88.

Oultram, J. D., Peck, H., Brehm, J. K., Thompson, D. E., Swinfield, T. J. \& Minton, N. P. (1988b). Introduction of genes for leucine biosynthesis from Clostridium pasteurianum into Clostridium acetobutylicum by cointegrate conjugal transfer. Molecular and General Genetics 214, 177-179.

Peijnenburg, A. A. C. M., Breed, P. V.. Bron, S. \& Venema, G. (1989). Plasmid deletion formation in recE4 and $a d d B 72$ mutants of Bacillus subtilis. Plasmid 21, 205-215.

Reysset, G. \& Sebald, M. (1985). Conjugal transfer of plasmid mediated antibiotic resistance from streptococci to Clostridium acetobutylicum. Annales de Microbiologie 136B, 275-282.
Simon, R., Priefer, U. \& Pühler, A. (1983). A broad host range mobilization system for in vivo genetic engineering: transposon mutagenesis in Gram negative bacteria. Bio/Technology 2, 784-791.

Swinfield, T. J., Oultram, J. D., Thompson, D. E., Brehm, J. K. \& Minton, N. P. (1990). Physical characterization of the replication region of the Streptococcus faecalis plasmid pAM $\beta 1$. Gene (in the Press).

Thomas, C. M. \& SMITH, C. A. (1987). Incompatibility group $\mathbf{P}$ plasmids: genetics, evolution, and use in genetic manipulation. Annual Review of Microbiology 41, 77-101.

TRIEU-CUOT, P. \& Courvalin, P. (1985). Transposition behaviour of IS 15 and its progenitor IS $15-\Lambda$ : are cointegrates exclusive end products? Plasmid 14, 80-89.

Trieu-Cuot, P., Carlier, C., Martin, P. \& Courvalin, P. (1987). Plasmid transfer by conjugation from Escherichia coli to Grampositive bacteria. FEMS Microbiology Letters 48, 289-294.

VAN DeR Lelie, D. \& Venema, G. (1987). Bacillus subtilis generates a major specific deletion in pAM $\beta 1$. Applied and Environmental Microbiology 53, 2458-2463.

Vieira, J. \& Messing, J. (1982). The pUC plasmids, an M13mp7derived system for insertion mutagenesis and sequencing with synthetic universal primers. Gene 19, 259-268.

Vosman, B. \& Venema, G. (1983). Introduction of a Streptococcus cremoris plasmid in Bacillus subtilis. Journal of Bacteriology 156, 920 921.

Willets, N. \& Wilkins, B. (1984). Processing of plasmid DNA during bacterial conjugation. Microbiology Reviews 48, 24-41.

Williams, D. R.. Young, D. I., Oultram, J. D., Minton, N. P. \& YounG, M. (1990). Development and optimization of conjugative plasmid transfer from Escherichia coli to Clostridium acetobutylicum NCIB 8052. In Anaerobes in Medicine and Industry. Edited by S. P. Borriello \& J. M. Hardie. Petersfield: Wrightson Biomedical (in the press).

Woolley, R. C., Pennock, A., Ashton, R. J., Davies, A. \& Young, M. (1989). Transfer of $\mathrm{Tn} 1545$ and $\mathrm{Tn} 916$ to Clostridium acetohutylicum. Plasmid 22, 169-174.

Yanisch-Perron, C., Vieira, J. \& Messing, J. (1985). Improved M13 cloning vectors and host strains: nucleotide sequences of the M13mp18 and pUC19 vectors. Gene 33, 103-119.

Young, M., Minton, N. P. \& Staudenbauer, W. L. (1989). Recent advances in the genetics of the clostridia. FEMS Microbiology Reviews 63, 301-326.

Yu, P.-L. \& Pearce, L. E. (1986). Conjugal transfer of streptococcal antibiotic resistance plasmids into Clostridium acetobutylicum. Biotechnology Letters 8, 469-474. 